\title{
KONSTRUKSI GENDER TOKOH UTAMA DALAM NOVEL AKU JALAK BUKAN JABLAY
}

\author{
Yusup Wibisono*1, Yukhsan Wakhyudi ${ }^{2}$ \\ 1,2Prodi Pendidikan Bahasa dan Sastra, Fakultas Keguruan dan Ilmu Pendidikan, \\ Universitas Peradaban, Indonesia \\ e-mail: *1yusup402@yahoo.com, ${ }^{2}$ zafranalyukhsan@gmail.com
}

\begin{abstract}
ABSTRAK
Penelitian berjudul Konstruksi Gender Tokoh Utama dalam Novel Aku Jalak Bukan Jablay Karya Aira Miranty Dewi Sebuah Kajian Posfeminisme, tujuan penelitian adalah memaparkan konstruksi gender tokoh utama berdasarkan kajian posfeminisme. Pendekatan yang digunakan adalah pendekatan feminisme dari sudut pandang perempuan. Sedangkan metode yang digunakan adalah deskriptif analitik, dengan data adalah teks yang mengandung konstruksi gender tokoh utama. Hasil dari penelitian ini menunjukkan bahwa konstruksi gender tokoh utama dalam novel yang dikaji berdasarkan perspektif posfeminisme terdiri dari tiga konstruksi. Konstruksi gender yakni, peran gender, identifikasi karakter, dan relasi gender. Peran gender dispesifikasikan menjadi aspek sikap tokoh utama, perilaku tokoh utama, dan profesi tokoh utama. Identifikasi karakter dispesifikasikan menjadi 2 konstruksi yakni fungsi gender dan hak gender. Fungsi gender dispesifikasikan menjadi 2 aspek yakni aspek kodrat perempuan pada tokoh utama dan aspek tanggungjawab pada tokoh utama. Hak gender dispesifikasikan menjadi 3 aspek yakni, aspek intuisi pada tokoh utama, aspek perlakuan baik pada tokoh utama, dan aspek proteksi pada tokoh utama. Sedangkan relasi gender dispesifikasikan menjadi 3 relasi yakni relasi gender pasangan, relasi gender nonpasangan, dan relasi sosial
\end{abstract}

Kata kunci: konstruksi, novel, posfeminisme

\begin{abstract}
Research entitled Gender Construction Main Figure in Novel Aku Jalak Bukan Jablay by Aira Miranty Dewi A Study of Postfeminism, the research objective is to explain the gender construction of the main character based on the study of posfeminism. The approach used is the approach of feminism from the point of view of women. While the method used is descriptive analytic, with the data being the text that contains the main character's gender construction. The results of this study indicate that the gender construction of the main characters in the novel studied based on the perspective of posfeminism consists of three constructs. Gender construction that is, gender roles, character identification, and gender relations. Gender roles are specified into aspects of the main character's attitudes, behavior, and profession. Character identification is specified into 2 constructs namely gender function and rights. The gender function is specified in 2 aspects, namely the nature of women in the main characters and aspects of responsibility. Gender rights are specified into 3 aspects, namely, the intuition aspect of the main character, good treatment, and protection. While gender relations are specified into 3 relations, namely the gender relations of couples, non-paired gender, and social
\end{abstract}

Keywords: construction, novel, posfeminisme

\section{PENDAHULUAN}

Karya sastra merupakan hasil cipta karya manusia, di dalamnya mengandung berbagai macam fenomena sebagai sebuah rekaman atas apa yang ada dan hadir di dalam masyarakat. Sebagai sebuah karya imajiner, fiksi menawarkan berbagai permasalahan manusia dan 
kemanusiaan, hidup dan kehidupan. Pengarang menghayati berbagai permasalahan tersebut dengan penuh kesungguhan yang kemudian diungkapkannya kembali melalui sarana fiksi sesuai dengan pandangannya[1]. Salah satu fenomena yang muncul adalah hadirnya sastra yang membahas tentang perempuan. Hal ini muncul sebagai bagian dari adanya persoalan gender dalam kehidupan masyarakat.

Fenomena perempuan di dalam dunia sastra, ditandai dengan munculnya novel-novel feminis sebagai bagian dari karya sastra modern. Kondisi ini merupakan perwujudan nyata dari sebuah perjuangan perempuan. Selain itu, sastra feminis juga menjadi sebuah komoditas utama di dalam sastra yang sangat disukai oleh masyarakat umum. Terdapat tiga alasan, mengapa masyarakat menyukai sastra feminis. Pertama, tema utama sastra feminis adalah tentang perempuan. Kedua, adanya anggapan yang berkembang di dalam masyarakat, bahwa populasi perempuan itu lebih banyak daripada populasi laki-laki. Ketiga, adanya kondisi yang timpang pada perempuan. Alasan-alasan tersebutlah yang menyebabkan sastra feminis disukai dan banyak diproduksi. Secara sederhana, sastra feminis itu berarti sastra yang berperspektif perempuan. Inti dari sastra feminis adalah upaya pemahaman kedudukan dan peran perempuan seperti tercermin dalam karya sastra[2]. Maka dapat dipahami bahwa sastra feminis adalah sastra yang mengangkat tema perempuan dengan segala kondisi yang dialaminya dan perjuangan yang dilakukannya. Jika dipahami lebih dalam, inti dari sastra feminis pada dasarnya adalah masalah gender. Inti dari sastra feminis ini akan terus berkembang sesuai dengan kondisi yang ada dan tuntutan yang terus muncul, salah satunya seperti emansipasi perempuan. Masalah prasangka gender dan (yang kemudian mendorong munculnya) emansipasi perempuan terus berkembang[2]. Salah satu perkembangannya adalah adanya fenomena sastra feminis yang menjadikan perempuan sebagai komoditas yang mewah, unik, menarik, dan yang paling penting adalah komersial sebagai salah satu tema utama dalam industri sastra. Tema yang ditampilkan tidak akan jauh dari hal-hal perempuan sebagai orang lemah lembut, permata, bunga[3].

Permasalahan gender memang menjadi hal yang tidak pernah selesai untuk dibahas. Gender berarti perbedaan antara laki-laki dan perempuan yang bukan biologis dan bukan kodrat Tuhan[2]. Berdasarkan pendapat tersebut, dapat dipahami bahwa perbedaan biologis yakni perbedaan kelamin adalah kodrat dari Tuhan dan bersifat permanen, namun berbeda pada gender. Hal ini dikarenakan gender adalah perbedaan perilaku antara lakilaki dan perempuan yang dikonstruksikan secara sosial dan kultural yang panjang. Berdasarkan pendapat tersebut, secara tidak langsung membenarkan penilaian yang ada bahwa persoalan gender akan tetap menjadi hal yang selalu dibahas.

Persoalan gender yang diwujudkan dengan adanya gerakan pengarusutamaan gender (PUG) melalui jalur pendidikan formal, mulai ramai diperdebatkan bukan hanya di dalam sastra saja. Di dalam konteks nyatanya, persoalan gender memang benar-benar menjadi masalah yang pelik untuk terus menerus dibahas. PUG yang dianggap menjadi bagian dari gerakan feminisme ini bertujuan untuk mengikis habis bias ketimpangan gender antara laki-laki dengan perempuan. Salah satu strategi formal yang dilakukan oleh pemerintah sebagai pemegang otoritas tertinggi 
adalah dengan menerbitkan Inpres No. 9 / 2000 Tentang Pengarusutamaan Gender dalam Pembangunan Nasional. Titik balik dari hal tersebut adalah kesetaraan pada peran dan tanggung jawab antara kaum perempuan (feminis) dengan kaum laki-laki dalam segala aspek kehidupan. Berdasarkan kondisi tersebut, maka tidak mengherankan jika persoalan gender masih menjadi sebuah hal yang terus menerus dibahas dan diperdebatkan hingga saat ini. Penilaian ini muncul dikarenakan bukan hanya secara nonformal (gerakan bawah tanah/ilegal) saja persoalan gender menjadi pusat perhatian. Tetapi secara formal (legal) persoalan gender juga menjadi sebuah fokus utama yang terus menerus dibahasa sesuai dengan perkembangan zaman.

\section{KAJIAN TEORI}

\section{Gender, Feminisme, dan Posfeminisme \\ a. . Gender}

Kata gender secara etimologi berasal dari bahasa Inggris gender yang berarti "jenis kelamin". Namun, juga ada anggapan bahwa kata gender berasal dari bahasa Latin yakni genus yang berarti jenis atau tipe[4]. Pengertian etimologis ini menekankan hubungan laki-laki dan perempuan secara anatomis sehingga dapat dipahami bahwa kata gender sudah mengacu pada hubungan laki-laki dan perempuan. Pengertian ini akan semakin luas jika dikaitkan dengan kompleksitas kehidupan sosial masyarakat yang ada. Hubungan laki-laki dan perempuan ini akan bertambah rumit dan terkesan berkelas-kelas jika dilihat pada masyarakat yang menganut sistem patriarki. Konstruksi gender secara umum diidentifikasikan melalui tiga hal, yaitu peran gender, identifikasi karakter, dan relasi gender[5]. Bila konsep seks didasarkan pada fisik, maka gender dibangun berdasar konstruksi sosial maupun kultural manusia[6].

\section{b. Feminisme}

Feminis berasal dari kata "femme" (woman), berarti perempuan (tunggal) yang berjuang untuk memperjuangkan hak-hak kaum perempuan (jamak) sebagai kelas sosial[7]. Orang yang menganut paham feminisme disebut feminis. Feminisme adalah sebuah teori tentang persamaan antara laki-laki dan perempuan dibidang politik, ekonomi, dan sosial atau kegiatan terorganisasi yang memperjuangkan hak-hak serta kepentingan perempuan[2].

\section{c. Posfeminisme}

Posfeminisme adalah gerakan yang muncul untuk menanggapi kelemahan dan kegagalan yang dialami feminisme gelombang kedua. Posfeminisme dianggap sebagai "jalan baru" bagi upaya sebagian perempuan untuk melakukan kritik dan otokritik dari dalam dan dari luar gerakan feminis yang memberikan suara lain bagi gerakan perempuan untuk memperbaiki kehidupannya, baik dalam lingkungan kerja maupun keluarga, baik dunia pemikiran maupun dunia aktivisme, baik dalam lingkungan real maupun lingkungan simbolik, baik dunia sosial maupun dunia media[8]. Konsep "pos" di dalam kata posfeminisme merujuk pada proses transformasi dan perubahan yang sedang berlangsung. Posfeminisme dapat dipahami sebagai perjumpaan kritis dengan patriarki dan pos-modernisme sebagai pertemuan kritis yang sama dengan prinsip-prinsip modernisme[8].

Alasan munculnya posfeminisme adalah karena feminisme gelombang kedua dianggap telah bertindak terlalu jauh dari cita-cita utama gerakan 
feminisme yakni sebuah kesejajaran. Penilaian ini muncul dikarenakan pada kenyataannya feminisme gelombang kedua bukan hanya berusaha untuk mencapai sebuah kesejajaran dalam arti sebenarnya, tetapi telah menjurus pada sebuah "dominasi baru". Gerakan ini mengacu pada kenyataan yang menyatakan bahwa pada dasarnya tidak ada catatan penindasan yang benar bagi semuaperempuan dalam segala situasi sepanjang masa[9]. Di dalam hal ini, inti dari posfeminisme adalah menentang asumsi dasar feminis yang menyatakan bahwa penindasan perempuan bersifat universal, yang berarti setiap perempuan akan mengalami suatu kondisi penindasan yang serupa di semua tempat yang diakibatkan oleh adanya diskriminasi gender[8]. Dengan demikian dapat dipahami bahwa feminisme gelombang ketiga ini memperjuangkan tujuan baru yakni dekonstruksi konsep dasar gerakan feminisme yakni dari "persamaan" ke dalam "perbedaan".

\section{Tokoh di dalam Karya Sastra}

Tokoh cerita (character) adalah orangorang yang ditampilkan dalam suatu karya naratif, atau drama, yang oleh pembaca ditafsirkan memiliki kualitas moral dan kecenderungan tertentu seperti yang diekspresikan dalam ucapan dan apa yang dilakukan dalam tindakan[1]. Sedangkan penokohan adalah pelukisan gambaran yang jelas tentang seseorang yang ditampilkan dalam sebuah cerita[1]. Dengan demikian istilah "penokohan" lebih luas pengertiannya daripada "tokoh" sebab ia sekaligus mencakup masalah siapa tokoh cerita, bagaimana perwatakan, dan bagaimana penempatan dan pelukisannya dalam sebuah cerita sehingga sanggup memberi gambaran yang jelas kepada pembaca.

\section{Kritik Feminis}

Kritik feminis adalah satu kritik (sastra) yang berusaha mendeskripsikan dan menafsirkan (serta menafsirkan kembali) pengalaman perempuan dalam berbagai karya sastra terutama dalam novel dan agak jarang dalam drama atau puisi [10]. Kritik sastra feminis bermula dari konsep reading as woman (membaca sebagai perempuan)[2]. Menurut pendapat tersebut, membaca sebagai perempuan adalah kesadaran pembaca bahwa ada perbedaan penting dalam jenis kelamin pada makna dan perebutan makna karya sastra. Selain itu pemahaman "membaca sebagai perempuan" juga dipahami sebagai perempuan yang berpandangan bahwa kritik ini tidak mencari metodologi atau model konseptual tunggal, tetapi sebaliknya yakni menjadi plural (majemuk). Di dalam teori dan praktiknya, kritik ini juga menggunakan kebebasan dalam metodologi dan pendekatan yang dapat membantu pelaksanaannya. Hal ini berdasarkan pada anggapan bahwa secara nyata ada kesadaran pembaca yang menyatakan bahwa terdapat pengaruh pada perbedaan jenis kelamin yang pada akhirnya akan mempengaruhi dunia sastra.

\section{METODE PENELITIAN}

Data dalam penelitian ini adalah teks yang mengandung konstruksi gender tokoh utama dalam novel Aku Jalak Bukan Jablay karya Aira Miranty Dewi. Sumber data dalam penelitian ini adalah novel Aku Jalak Bukan Jablay karya Aira Miranty Dewi. Adapun pendekatan yang digunakan dalam penelitian ini adalah pendekatan feminisme. Objek penelitian dari penelitian ini adalah konstruksi gender tokoh utama dalam novel Aku Jalak Bukan Jablay karya Aira Miranty Dewi. Sementara itu, 
Metode yang digunakan dalam penelitian ini adalah metode deskriptif analisis. Langkah kerja dari penelitian ini meliputi lima tahapan meliputi: membaca novel secara berulang-ulang dan dilakukan secara intensif (membaca pemahaman); telaah pustaka yang sesuai dan dapat mendukung terhadap penelitian ini; inventarisasi data yaitu dengan dengan cara mengklasifikasikan data sesuai dengan hal-hal yang berkaitan dengan konstruksi gender tokoh utama yang berdasarkan pada perspektif posfeminisme; analisis novel dan pendeskripsian hasil analisis. Analisis yang dilakukan bertujuan untuk membahas tentang konstruksi gender tokoh utama berdasarkan pada perspektif posfeminisme; menyimpulkan hasil analisis.

\section{HASIL DAN PEMBAHASAN}

\section{Peran gender dispesifikasikan menjadi aspek sikap tokoh utama, aspek perilaku tokoh utama, dan aspek profesi tokoh utama.}

a. Aspek sikap tokoh utama yang dilakukan oleh Miranty dengan mengacu pada adanya sifat "beda" atau "liyan"diwujudkan dengan adanya sikap keras yang berorientasi pada adanya eksistensi Miranty sebagai seorang perempuan di lingkungan masyarakat. Tujuan utama dari sikap keras yang ditunjukkan oleh Miranty ini adalah untuk menjaga eksistensinya di dalam masyarakat agar tetap diakui keberadaannya secara sosial. Miranty menyadari bahwasalah cara untuk mendapatkan pengakuan sosial bagi dirinya, memang harus dimulai dari posisi sebagai pihak yang dinilai aneh atau "liyan" karena harus bersikap keras "galak" di dalam kehidupan sehari-hari. b. Aspek perilaku tokoh utama yang dilakukan oleh Miranty dengan mengacu pada "beda" atau "liyan"yang diwujudkan dalam perilaku-perilaku yang berorientasi pada pengembalian kedudukan sosial. Hal ini dilakukan dengan cara Miranty harusdapat berperilaku proaktif sesuai aturan dan norma yang berlaku di dalam masyarakat. Pengembalian kedudukan ini berdasarkan pada penilaian sosial bahwa untuk diterima secara sosial, maka penyandang status "janda" diwajibkan agar berperilaku lebih proaktif di dalam pergaulan sosial sebagai wujud adanya usaha dan pengorbanandarinya.Perilaku ini dilakukan agar tidak memunculkan anggapan-anggapan negatif yang ditujukan padanya.Dengan berperilaku sesuai aturan dan norma yang berlaku itulah, Miranty berusaha agardapat diterima penuh (apa adanya) sebagai bagian dari anggota masyarakat.

c. Aspek profesi tokoh utama yang dilakukan oleh Miranty dengan mengacu pada "beda" atau "liyan" yang diwujudkan dalam hal-hal yang berorientasi pada adanya usaha untuk memperbaiki kehidupannya dalam bidang privat, publik, dan dunia kerja.Hal tersebutdilakukan sebagai sebuah "jalan baru" bagi Miranty yang mewakili kaum perempuan untuk tetap dapat diakui sekaligus diterima sebagai anggota masyarakat.Kondisi ini muncul karena Miranty dinilai telah sadar akan pilihan hidupnya sebagai seorang perempuan. Dengan aspek profesi ini,secara tidak langsung telah mengembalikan kedudukannya sebagai perempuan yang sebenarnya yakni diakui sebagai manusia yang potensial dan prestatif. Pengembalikan kedudukan ini 
Jurnal SEMANTIKA, Volume 1, No. 01, Agustus 2019, p. 11-19

dilakukan dengan cara tetap memilih menjadi perempuan dalam menjalankan karirnya, yang secara tidak langsung telah menampilkan konsep, sikap, tata kerja, dan etos kerja perempuan yang pada dasarnya jauh berbeda dari laki-laki pada saat bekerja.

\section{Identifikasi dispesifikasikan menjadi dua konstruksi yakni fungsi gender dan hak gender. Inti dari masing-masing konstruksi tersebut sebagai berikut.}

a. Fungsi gender dispesifikasikan menjadi dua aspek yakni aspek kodrat perempuan pada tokoh utama dan aspek tanggung jawab pada tokoh utama.

1) Aspek kodrat perempuan pada tokoh utama mengacu pada "beda" atau "liyan" yang diwujudkan dalam berbagai tindakan yang berorientasi pada adanya pengembalian roh perempuan pada Miranty yakni dengancara menjadiseorang ibu. Pengembalian roh perempuan pada Miranty merupakan sebuah kodrat bagi perempuan yang secara hakiki membedakannya dari kodrat laki-laki. Roh tersebut berwujud adanya sebuah kesadaran akan pilihan hidup untuk menjadi seorang ibu.Dengan pilihan hidup menjadi seorang ibu secara tidak langsung telah membuat Miranty memperoleh rohnya sebagai perempuan, sekaligus membedakannya dari laki-laki secara kodrati.

2) Aspek tanggung jawab pada tokoh utama mengacu pada "beda" atau "liyan" yang diwujudkan dalam berbagai tindakan yang berorientasi pada adanya sebuah usaha pemenuhan terhadap setiap tanggung jawab yang dinilai "berbeda". Pemenuhan tanggung jawab yang dinilai "berbeda" inidilakukan oleh Miranty dengan cara melaksanakan kewajiban dengan sebaik-baiknya. Hal ini dikarenakan di dalam berbagai tanggung jawab yang diemban oleh Miranty itu mengacu pada konsep "beda" atau "liyan"yang bervariasi terutama pada fungsi ganda dan beban ganda yang melekat pada aspek tanggung jawab keluarga. Sedangkan kondisi "berbeda" yang muncul pada setiap tanggung jawab yang diembannya itu, pada dasarnya dikarenakan adanya status yang "beda" atau "liyan" dari Miranty tersebut. Hal tersebut memberikan kesempatan sekaligus menuntut Miranty untuk melakukan atau mewujudkan berbagai tanggung jawab yang berbeda dari perempuan lainnya, yaitu tanggung jawab sesuai dengan status yang disandangnya yang dinilai "berbeda" tersebut.

b. Hak gender dispesifikasikan menjadi tiga aspek yakni, aspek intuisi pada tokoh utama, aspek perlakuan baik pada tokoh utama, dan aspek proteksi pada tokoh utama.

1) Aspek intuisi pada tokoh utama mengacu pada "beda" atau "liyan" yang diwujudkan oleh Mirantydengan melakukan atau mewujudkan sebuah tindakan yang melahirkan sebuah keputusan yang berbeda dari perempuan lainnya. Keputusan ini berdasar pada intuisi yang diyakininya. Selain itu, sesuai dengan kodratnya sebagai perempuan yang berbeda dari 
Jurnal SEMANTIKA, Volume 1, No. 01, Agustus 2019, p. 11-19

laki-laki ditambah dengan status sosialnya sebagai seorang janda sekaligus sebagai seorang single parent semakin membuat Miranty "berbeda". Di dalam kondisi ini Mirantydituntut untuk dapat berperilaku dan bertindak berbeda. Salah satu cara yang dilakukannya adalah dengan wujud meyakini kebenaran dari intuisi yang datang padanya. Selain itu, aspek intuisi juga diwujudkan oleh Miranty dengan tindakantindakan yang berorientasi pada adanya aspek rasa. Di mana sifat dasar perempuan yang paling pokok adalah penggunaan aspek rasa dalam menilai segala sesuatu, yakni menilai apakah suatu hal itu baik ataupun buruk baginya. Selain itu, kepekaan perasaan perempuan yang ditampilkan oleh Miranty merupakan gambaran "beda" atau "liyan" antara laki-laki dengan perempuan di mana dalam menilai dan melakukan sesuatu perempuan lebih mengandalkan rasa, dalam hal ini intuisi. Sedangkan laki-laki lebih mengutamakan rasionalitas dan intelektualitas dalam menilai suatu hal.

2) Aspek perlakuan baik pada tokoh utama mengacu pada "beda" atau "liyan" yang diwujudkan oleh Mirantydenganmendapatkan perlakuan yang "berbeda" dari perempuan lainnya. Hal ini berorientasi pada status yang disandang oleh Miranty dan kondisi yang dialaminya. Oleh karena itu, Mirantydianggap sangat membutuhkan sebuah perlakuan "berbeda" yaitu adanya sebuah perlakuan baik untuk dapat mendukungnya dalam melaksanakan fungsi gandanya dan mengurangi beban ganda yang dipikulnya.

3) Aspek proteksi pada tokoh utama mengacu pada "beda" atau "liyan" yang diwujudkan oleh Miranty dengan sebuah perlindungan bertingkat. Perlindunganyang dilakukan oleh Miranty pada dasarnya berorientasi pada sebuah cara untuk melindungi diri, sekaligus sebagai sebuah cara untuk melawan terhadap setiap tindakan yang dinilainya negatif dan mengancamnya. Status sosial Miranty sebagai seorang janda membuatnya memiliki sifat "beda" atau "liyan" dari perempuan pada umumnya. Status janda tersebut, secara sosial mengundang adanya tindakan-tindakan negatif, stereotype, dan teror yang semuanya menyudutkan Miranty sebagai penyandangnya. Aspek proteksi digunakan oleh Miranty sebagai sebuah cara untuk berlindung sekaligus melawan. Perbedaan aspek sikap dan aspek proteksi adalah sebagai berikut, pada aspek sikap fokus utamanya adalah pada kepentingan "beda" untuk dapat eksis dan dapat diterima di dalam masyarakat sedangkan pada aspek proteksi fokus utamanya adalah lebih menjurus pada "beda" yang lebih fokus terhadap perlindungan dan perlawanan dari adanya berbagai ancaman.

\section{Relasi gender dispesifikasikan menjadi tiga relasi yakni,relasi gender pasangan, relasi gender nonpasangan, dan relasi sosial.}


a. Relasi gender pasangan acuan "beda" atau "liyan" tersebut diwujudkan dengan tindakan memberikan kesempatan sekaligus menuntut Miranty untuk melakukan hal yang"berbeda". Hal tersebutdiwujudkan dengan adanya keputusan untuk tetap menerima laki-laki sebagai pasangannya di dalam relasi gender pasangan. Kondisi ini muncul dari penilaian Miranty yang berasal dari adanya pilihan hidup sekaligus sebagai sebuah prinsip untuk melakukan hal yang"berbeda". "Berbeda" dalam hal ini diSEwujudkan dengan menilai laki-laki lebih proporsional. Penilaian ini mengacu bahwa pada dasarnya laki-laki itu juga penting bagi Miranty karena laki-laki mempunyai fungsi pokok sebagai pihak yang dapat melengkapi kekurangan dan keterbatasannya sebagai seorang perempuan.

b. Relasi gender nonpasangan, acuan "beda" atau "liyan" diwujudkan dalam tindakanMiranty menciptakan sebuah lingkungan pergaulan yang dinilainya dapat menerima dia apa adanya. Lingkungan pergaulan yang diciptakan oleh Miranty ini dibentuk dengan menerapkan "skala prioritas pergaulan". Isi dari "skala prioritas pergaulan" merupakan rangkaian prioritas-prioritas pergaulan yang disusun oleh Miranty atas dasar kedekatan yaitu adanya frekuensi (jumlah) interaksi yang tinggi (sering) yang menghasilkan kedekatan dan komunikasi yang kuat. Susunan skala prioritas yang diterapkan oleh Miranty di antaranya sebagai berikut: prioritas pertama adalah keluarga, prioritas kedua adalah sahabat, prioritas ketiga adalah teman dan prioritas keempat adalah atasan (rekan kerja di kantor). Semua yang dilakukan oleh Miranty pada dasarnya hanya sebuah caranya untuk menunjukkan adanya reaksi terhadap setiap perlakuan yang ditujukan padanya yang menilai dirinya "beda" dari anggota masyarakat lainnya.

c. Relasi sosial mengacu pada "beda" atau "liyan" yang diwujudkan oleh Miranty dengan memasuki lingkungan pergaulan yang "berbeda" dari lainnya. Hal ini terjadi karenadi dalam lingkungan tersebut Miranty dapat diterima apa adanya sebagai perempuan penyandang status janda sekaligus sebagai seorang single parent. Sedangkan alasan dasar mengapa Miranty memasuki lingkungan pergaulan yang "berbeda" ini di antaranya sebagai berikut: 1). Adanya status sosial yang "berbeda" dari Miranty yang ternyata dipandang sebelah mata di dalam pergaulan sosial. 2). Adanya kebutuhan sosialisasi dari Miranty yang tinggi. 3). Tingginya penghasilan dari Miranty. 4). Adanya pemikiran yang lebih proporsional terhadap laki-laki. 5). Munculnya sebuah kondisi di mana sahabat Miranty satu persatu harus berpindah tempat tinggal yang membuat mereka tidak dapat bertemu secara langsung di dalam satu tempat. Kondisi ini membuat adanya sebuah kekosongan pergaulan pada Miranty.

\section{SIMPULAN}

Berdasarkan analisis dan pembahasan yang telah dilakukan, maka dapat disimpulkan bahwa konstruksi gender tokoh utama dalam novel Aku Jalak Bukan Jablay karya Aira Miranty Dewi yang dikajian berdasarkan perspektif posfeminisme terdiri dari tiga konstruksi. Konstruksi gender tersebut yakni, peran gender, identifikasi karakter, dan relasi gender. Inti dari tiga konstruksi gender 
tersebut adalah peran gender dispesifikasikan menjadi aspek sikap tokoh utama, aspek perilaku tokoh utama, dan aspek profesi tokoh utama. Selain itu identifikasi karakter dispesifikasikan menjadi dua konstruksi yakni fungsi gender dan hak gender. Inti dari masingmasing kosntruksi tersebut sebagai berikut: Fungsi gender dispesifikasikan menjadi dua aspek yakni aspek kodrat perempuan pada tokoh utama dan aspek tanggung jawab pada tokoh utama. Dan hak gender dispesifikasikan menjadi tiga aspek yakni, aspek intuisi pada tokoh utama, aspek perlakuan baik pada tokoh utama, dan aspek proteksi pada tokoh utama.

Relasi gender dispesifikasikan menjadi tiga relasi yakni, relasi gender pasangan, relasi gender nonpasangan, dan relasi social

\section{REFERENCES}

[1] Nurgiyantoro, Burhan. 2012. Teori Pengkajian Fiksi.Yogyakarta: Gadjah Mada University Press.

[2] Sugihastuti dan Suharto. 2010. Kritik Sastra Feminis Teori dan Aplikasi. Yogyakarta: Pustaka Pelajar

[3] Endraswara, Suwardi. 2011. Metodologi Penelitian Sastra.Yogyakarta: CAPS

[4] Kadarusman. 2005. Agama, Relasi Gender \& Feminisme. Yogyakarta: Kreasi Wacana Yogyakarta.

[5] Widyatama, Rendra. 2006. Bias Gender Dalam Iklan Televisi. Yogyakarta: Media Pressindo.

[6] Fakih, Mansour. 2012. Analisis Gender dan Trasformasi Sosial. Yogyakarta: Pustaka Pelajar

[7] Ratna, Nyoman Kutha. 2012. Teori, Metode, dan Teknik
Penelitian Sastra.Yogyakarta: Pustaka Pelajar.

[8] Brooks, Ann. 2011.Posfeminisme \& Cultural Studies. terj. S. Kunto Adi Wibowo.Yogyakarta: Jalasutra.

[9] Gamble, Sarah. 2010. Feminisme \& Postfeminisme. terj. Tim PenerjemahJalasutra. Yogyakarta: Jalasutra

[10] Pradotokusumo, Partini Sardjono. 2008. Pengkajian Sastra. Jakarta: PT Gramedia Pustaka Utama 